\title{
Impact of Land-Use Change on Soil Carbon Dynamics in Tropical Peatland, West Kalimantan- Indonesia
}

\author{
Rossie Wiedya Nusantara ${ }^{{ }^{*}}$, Sudarmadji ${ }^{2}$, Tjut S. Djohan ${ }^{3}$ and Eko Haryono ${ }^{2}$ \\ ${ }^{1}$ Faculty of Agriculture Tanjungpura University, Pontianak, West Kalimantan, Indonesia. ${ }^{2}$ Faculty of \\ Geography Gadjah Mada University, Bulaksumur, Yogyakarta, Indonesia. ${ }^{3}$ Faculty of Biology Gadjah \\ Mada University, Bulaksumur, Yogyakarta, Indonesia.
}

Received: 2019-08-05 Accepted: 2019-12-27

\section{Key words:}

Tropical peat forest;

land-use change land

conversion;

soil organic C;

stable carbon isotope $\left(\delta^{13} \mathrm{C}\right)$.

Correspondent email:

rwiedyanusantara@gmail.com

\begin{abstract}
The conversion of tropical peat forest to other land uses can reduce organic carbon (C) and stable $\mathrm{C}$ isotope $\left(\delta^{13} \mathrm{C}\right)$ of peat soil. This research aimed at analyzing the soil organic-C and $\delta^{13} \mathrm{C}$ of peatland with respect to maturity (fibric, hemic and sapric) in five types of peatland use, which included primary peat forest, secondary peat forest, shrubs, oil palm plantations, and cornfield in West Kalimantan. Analysis of peat soil samples includes organic $\mathrm{C}$ with Loss in ignition method and $\delta^{13} \mathrm{C}$ using an isotope ratio mass spectrometry(IRMS) method. Organic-C at fibric was higher than hemic and sapric, respectively (57.2\%, $57.0 \%, 56.4 \%)$, meanwhile, organic- $C$ was the highest on primary peat forest, followed by on secondary peat forest, oil palm plantation, cornfield, and shrubs, respectively $57.1 \%, 57.0 \%, 56.4 \%, 56.0 \%$. The cause of increasing and decreasing organic $\mathrm{C}$ and $\delta^{13} \mathrm{C}$ due to land-use change due to changes in vegetation, burning during tillage, and age of organic matter of peat soil. This condition causes the opening of natural peat ecosystems and changes in anaerobic to aerobic conditions.
\end{abstract}

2020 by the authors. Licensee Indonesian Journal of Geography, Indonesia.

This article is an open access article distributed under the terms and conditions of the Creative Commons

Attribution(CC BY NC) licensehttps://creativecommons.org/licenses/by-nc/4.0/.

\section{Introduction}

Tropical peatlands cover approximately 27 million ha in Southeast Asia, distributed in Malaysia and Indonesian lowlands, particularly in Kalimantan, Sumatera, West Papua, and Malaysia Peninsula (Page et al. 2007; Hooijer et al. 2010). Tropical peats store substantial stocks of soil carbon (C), due to the anaerobic soil conditions restricting decomposition of organic matter (Page et al. 2011) (Farmer 2013). The existence of peat swamp forests in Indonesia endangered due to the pressure from various human activities. The conversion of forest into agricultural land, plantation, and production forest may threaten the existence of a natural peat swamp forest. Changes in land use activities in the area can be the establishment of drainage channels, land clearing in the form of deforestation, logging and shrubs cutting, burning to land clearance as well as land preparation such as planting line compaction and planting bed practices (Radjagukguk 2000, Limpens et al. 2008, Page et al. 2009, Ojanen et al. 2012, Farmer 2011, Wösten et al. 2008). The impact of peat swamp forest destruction significantly contributes to the environment a result of the massive losses of soil $\mathrm{C}$ and a large number of $\mathrm{C}$ released to the atmosphere during such destruction (Hooijer et al. 2010).

The conversion of land use has the potential to change the dynamics of soil organic matter. Stable $C$ isotope $\left(\delta^{13} C\right)$ can be used to study the environmental change during land-use change or to investigate the degradation processes of peatlands (Krüger et al. 2015). The abundance of $\delta^{13} \mathrm{C}$ can be used to predict the rate of accumulation and loss of soil $\mathrm{C}$ as a result of land-use change, decomposition and humification level of soil organic matter as well as to reconstruct the past changes in soil organic matter (SOM) from plants with dominant $\mathrm{C}_{3}$ photosynthesis pathway into plants with $\mathrm{C}_{4}$ photosynthesis pathway or vice versa (Bernoux et al. 1998, Balesdent et al., n.d., Lane et al. 2004, Marin-Spiotta et al. 2009). Depth profiles of stable carbon isotopes generally reflect organic matter dynamics in soils with a decrease of $\delta^{13} \mathrm{C}$ values during aerobic decomposition and stable or increase $\delta^{13} \mathrm{C}$ values with depth during anaerobic decomposition (Krüger et al. 2015)

Detail studies on the dynamics of $\mathrm{C}$ in tropical peatland, particularly based on the peat maturity (sapric, hemic, fibric) in Indonesia, are very limited. Most of the studies were conducted on mineral land and some on temperate peatlands. Therefore, this study presents the peat soil $\mathrm{C}$ dynamics and $\delta^{13} \mathrm{C}$ of peatland as the result of peatland conversion, from primary peat forest into secondary peat forest, shrubs, oil palm plantation, and cornfield. The purpose of this research 
was to analyze the dynamics of soil organic C (SOC) and $\delta^{13} \mathrm{C}$ based on the peat maturity within several types of peatland. The research hypothesizes that SOC and $\delta^{13} \mathrm{C}$ respond to aerobic-anaerobic conditions and maturity peat as the result of land-use change.

\section{The Methods}

The study area was five types of peatland, namely: (1) primary peat forest (PPF), (2) secondary peat forest (SPF), (3) shrubs (SB), (4) oil palm plantation (OPP) and (5) cornfield (CF). The Map, coordinates, and description of the study area are presented in Figure 1 and Table 1.

\section{Peat samples}

We collected soil sampling in June until July 2014. Soil samples were collected by stratified random by considering peat maturity (fibric, hemic, sapric), then samples were randomly taken from each stratum, repeated for five times. The maturity level of the drilled peat was identified by using von Post scale (Notohadiprawiro 1985). Sapric, hemic, fibric identify decomposed peat, half-mature and immature peat, respectively. The depth of peat soil was measured by using peat sampler (Eijkelkamp) and measured based on the layer of peat maturity until reaching the layer of clay, grayishwhite soil. The peat maturity profile of each land use is presented in Figure 2. The peat maturity was made in composite from all layers of maturity on each profile of land type.

\section{Laboratory analyses}

Peat samples were air-dried for approximately one day or two. The soil then was separated from the plant's roots, gravel, and other dirt. Afterward, soil samples were prepared with a size of $<2 \mathrm{~mm}$ and $<0.5 \mathrm{~mm}$ by pounding and sifting until the soil samples were ready to be analyzed. Soil C-organic (\%) and ash were determined based on loss on ignition (LoI) (Agus et al. 2011) and total $\mathrm{N}$ concentrations were measured with a spectrophotometer (Uv-Vis Hitachi U-2010) in the laboratory of Indonesian Soil Research Institute in Bogor, Indonesia. Stable isotope abundances are expressed, using the $\delta$ notation in per mil (\%), as the deviation of the isotopic ratio of the sample from that of an arbitrary standard, where:

$\delta^{13} \mathrm{C}=\left[\left(\frac{R \text { sample }}{R \text { standard }}\right)-1\right] \times 1000$, R sample $={ }^{13} \mathrm{C} /{ }^{12} \mathrm{C}$ of the sample, and $\mathrm{R}$ standard = the Pee Dee Belemnite (PDB) standard (Choi et al. 2007). The $\mathrm{C} / \mathrm{N}$ ratio represents the atomic relationship between carbon and nitrogen content of peat soil.

\section{Data Analysis}

Treatment effects were tested using analysis of variance (ANOVA), and means of treatments were compared using Duncan's New Multiple Range Test at $P \leq 0.05$. The correla- tion between $\delta^{13} \mathrm{C}$ and ratio $\mathrm{C} / \mathrm{N}$ and ah content were analyzed using Pearson correlation analysis.

\section{Results and Discussion \\ Soil Organic Carbon}

Soil organic carbon (SOC) based on land use and peat maturity in the study ranged from $54.8 \%$ to $58.0 \%$ (Figure 3). Such data indicated a tendency that SOC in fibric was higher (57.2\%) than that of hemic (57\%) and sapric (56.4\%). Meanwhile, based on the land use, it indicated a tendency that SOC in PPF was higher (57.9\%) than SPF (57.1\%), SB (57\%), OPP (56.4\%) and CF (56\%) respectively. Test between the land use with SOC is a difference, but for peat, maturity is not. C-organic arable land (CF and OPP) significantly different forest areas but not different shrubland.

At the study areas, peat forests had higher SOC than other lands ( $\mathrm{SB}, \mathrm{OPP}$, and $\mathrm{CF}$ ). It is totally normal, not only because peat absorbs more $\mathrm{C}$ as your reason, but also because in other land use (land use for maize etc.), SOC has been more mineralized than in forest land use. Similar to this result, Monde et al. (2008) suggested that forest area had total $\mathrm{C}$ absorption higher and significantly different from the land use for maize, peanut, agroforestry and cocoa, decreased by $91.2 \%$ to $99.4 \%$. (Tomich et al. 1985) reported that natural forest can storage of $\mathrm{C}$ higher than other land use, diminishing after being converted into agroforestry of vanilla and cocoa, by $44.5 \%$ and $41.0 \%$. According to (Sarkhot et al. 2007), intensively processed land may reduce soil C content for $23.0 \%$.

The changes of long-term land use results in the difference in quantity and composition of soil organic materials or soil C content, and soil fertility (Prentice and Webb 2010, Tan and Lal 2005). Similarly to this result, (Del Galdo et al. 2003) report that conventional agricultural use decreased soil organic C by $48.0 \%$ in the 10 top and only $3.0 \%$ in the more in-depth profile. Meanwhile, Qiming et al. (2003), Firdaus et al. (2010, and Satrio et al. (2009) suggested that SOM in forestland higher than farmland decreased by $87.0 \%, 1.0 \%$, and $4.7 \%$, respectively. Several possible explanations could be proposed in the present case : (1) inorganic fertilizers may enhance microbial activity and nutrient availability but reducing the stabilize organic matter; (2) physical protection of SOM within stable aggregates may be affected by soil tillage (Qiming et al. 2003); (3) greater soil aeration during and after opening the peat swamp forest might have caused breakdown of organic residues and hence encouraged decomposition of organic matter by microbes (Brady and Weil 2007).

The aforementioned explanations describe that the change in the land use of primary peat swamp forestry accompanied by making drainage and processing land intensively will change its natural ecosystem, which is anaerobic. 


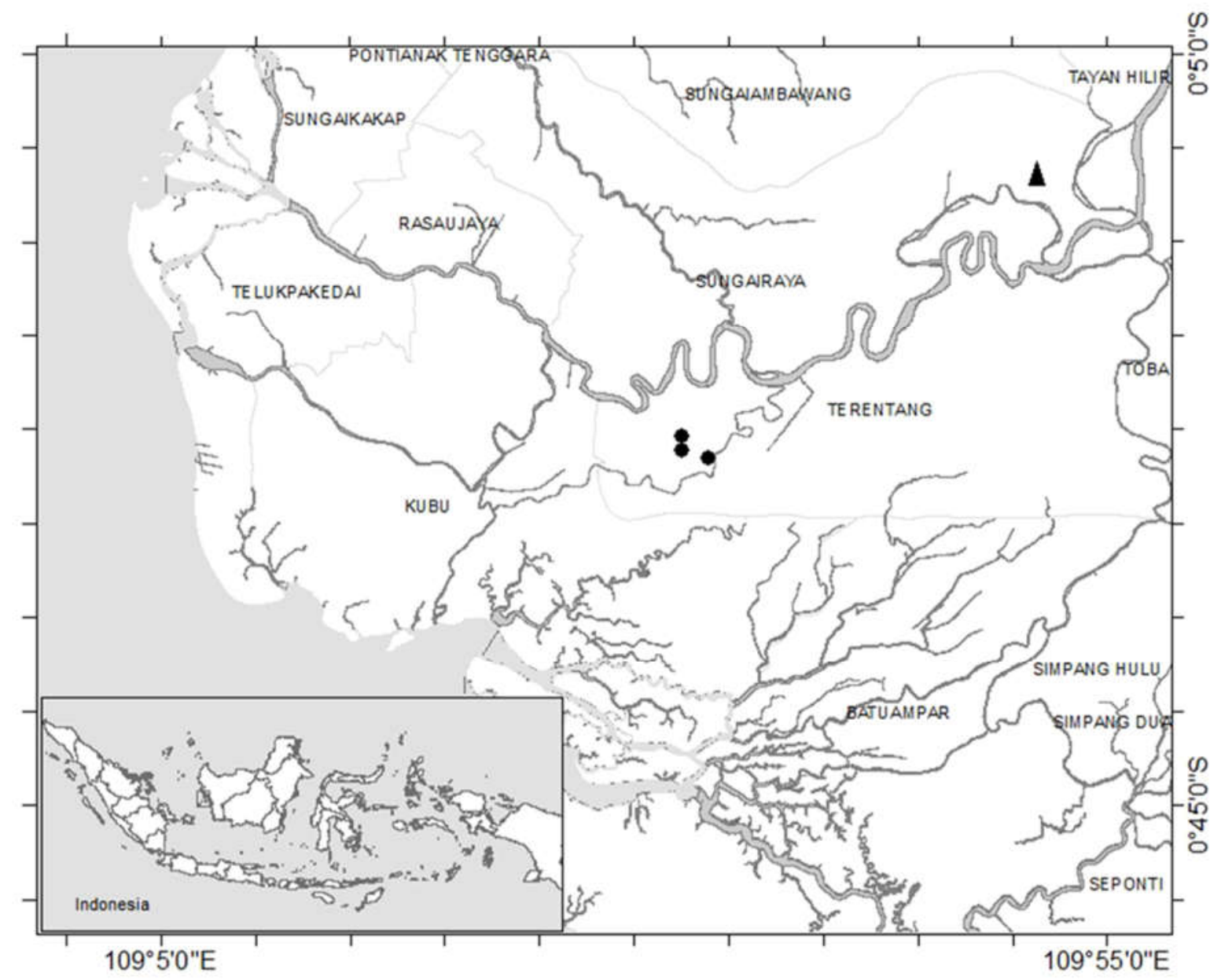

Figure 1. Sampling sites on the study area of primary peat forest, secondary peat forest, shrubs, oil palm plantation, and cornfield

Land

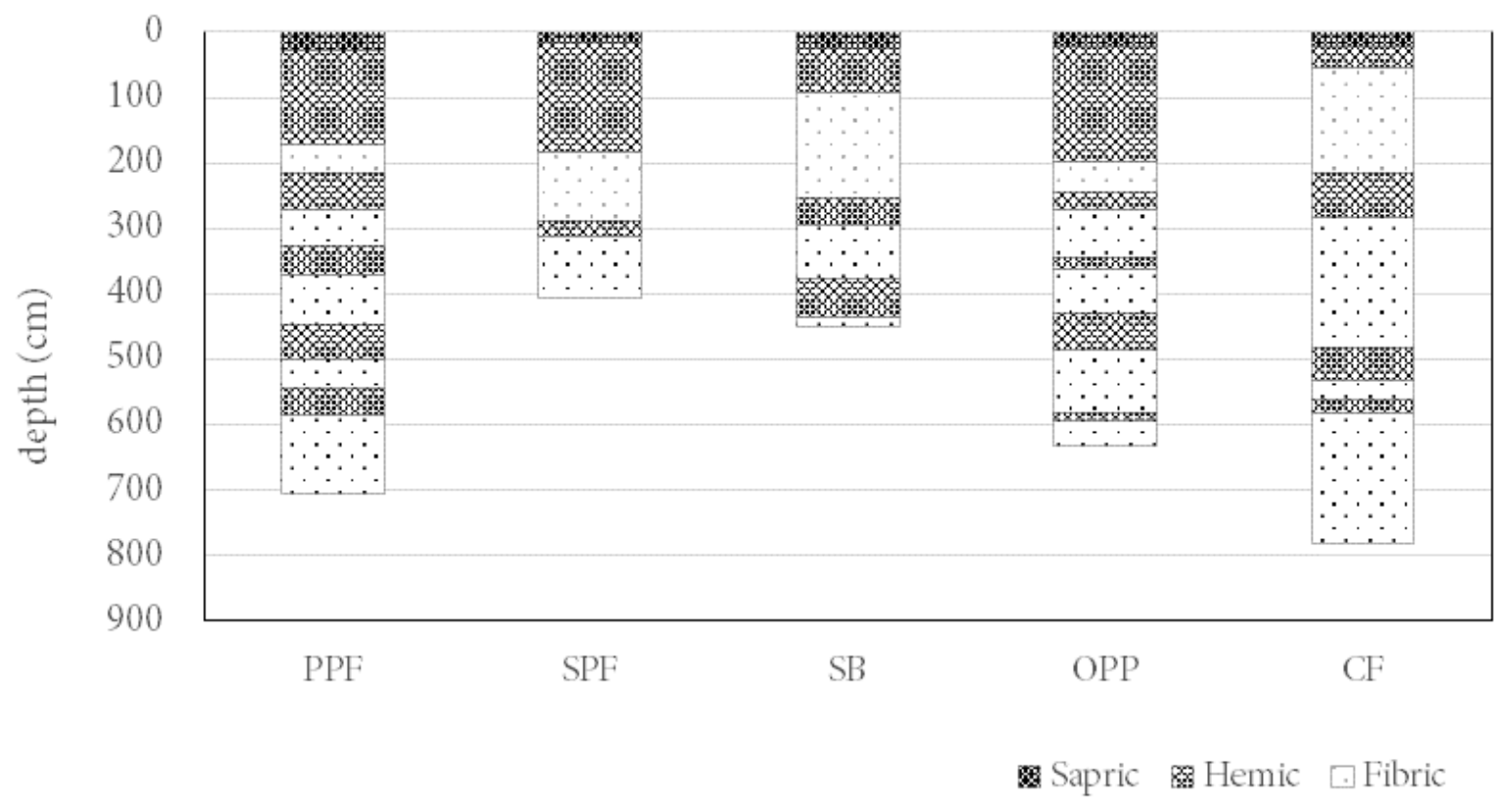

Figure 2. Profile of peat maturity on the type of primary peat forest, secondary peat forest, shrubs, oil palm plantation and cornfield 
Table 1. Description of the study area

\begin{tabular}{ll}
\hline Land & Location \\
& \\
\hline Primary peat & Sungai Raya Subdistrict, \\
forest & Kubu Raya Regency - \\
& $16.649 \mathrm{~m}^{2}$ \\
& $\mathrm{~S}=00^{\circ} 11.287$ until 355 \\
& $\mathrm{E}=109^{\circ} 49.456$ until 618
\end{tabular}

Secondary Kubu Subdistrict- Kubu peat Forest Raya Regency - $16.333 \mathrm{~m}^{2}$ $\mathrm{S}=00^{\circ} 21.697$ until 814 $\mathrm{E}=109^{0} 21.813$ until 928

Shrubs

Oil palm plantation

Kubu Subdistrict- Kubu Raya Regency - $26.299 \mathrm{~m}^{2}$ $\mathrm{S}=00^{0} 23.874$ until 962 $\mathrm{E}=109^{0} 22.648$ until 718

Corn field Rasau Jaya SubdistrictKubu Raya Regency $26.680 \mathrm{~m}^{2}$ $\mathrm{S}=00^{0} 12.759$ until 897 $\mathrm{E}=109^{\circ} 23.552$ until 719
In this location, there were road and drainage channel crossing Protected Peat Forest. Road and drainage construction was a part of the National Program for Community Empowerment (PNPM) activities conducted in the middle of 2011. The road was $5 \mathrm{~km}$ long and $400 \mathrm{~cm}$ wide, while the drainage channel is $350 \mathrm{~cm}$ wide and water level of $100 \mathrm{~cm}$. While surveying the location in February 2011, the condition of HP was in the natural condition with a muddy peatland surface and water level of approximately 1-2 cm. The dominant vegetation in the location included Ubah (Syzygium spp.), Tanjan (Dialium spp.), Mahang (Macaranga pruinosa), Rengas (Drmycarpus spp.), Kayu malam (Diospyros borneensis), Kempas (Koompasia mala), Resak (Cotylelobium spp).

Water-table depth $=45.1 \mathrm{~cm}$; depth of peat soil $=507.2 \mathrm{~cm}$

In this location, there was a drainage channel (as the border of a protected forest) with a $180 \mathrm{~cm}$ wide and water level of $70 \mathrm{~cm}$. The dominant vegetation in this location included Tanjan (Dialium spp.), Rengas (Gluta renghas L.) .), Resak (Vatica rassak BL.), Bintagor (Calophyllum spp.), Ilas (Nephelium cuspidatum), Tanang (Calophyllum spp.).

Water-table depth $=32 \mathrm{~cm}$; depth of peat $\operatorname{soil}=311.2 \mathrm{~cm}$

In this location, the condition was varied; tree trunks of the logged over and burnt spread out in sampling 3 and 4 points. Another sampling point was in the form of shrubs. The dominant vegetation in the location included fern (Diplazium esculentum), pandanus forest (Pandanus tectorius) and cengkodok (Melastoma malabathricum) and wood from burned trees.

Water-table depth $=43.1 \mathrm{~cm}$, depth of peat soil $=394.0 \mathrm{~cm}$

In this location, there was a drainage channel circling around the block. The main drainage channel was $280 \mathrm{~cm}$ wide and water level of $40 \mathrm{~cm}$; channel of the right block was $100 \mathrm{~cm}$ wide and water level of $77 \mathrm{~cm}$; channel of the left block was 250 $\mathrm{cm}$ wide and water level of $30 \mathrm{~cm}$. There were also ferns as a cover crop. Water-table depth $=52.6 \mathrm{~cm}$, depth of peat soil $=441.0 \mathrm{~cm}$

In this location, there was a drainage channel, that the primary channel was 380 $\mathrm{cm}$ wide and had a water level of $40 \mathrm{~cm}$, the tertiary channel was $50 \mathrm{~cm}$ wide and had a water level of $20 \mathrm{~cm}$.

Water-table depth $=55.1 \mathrm{~cm}$, depth of peat soil $=475.6 \mathrm{~cm}$

\section{The description of the study area have been published (Nusantara, 2015)}

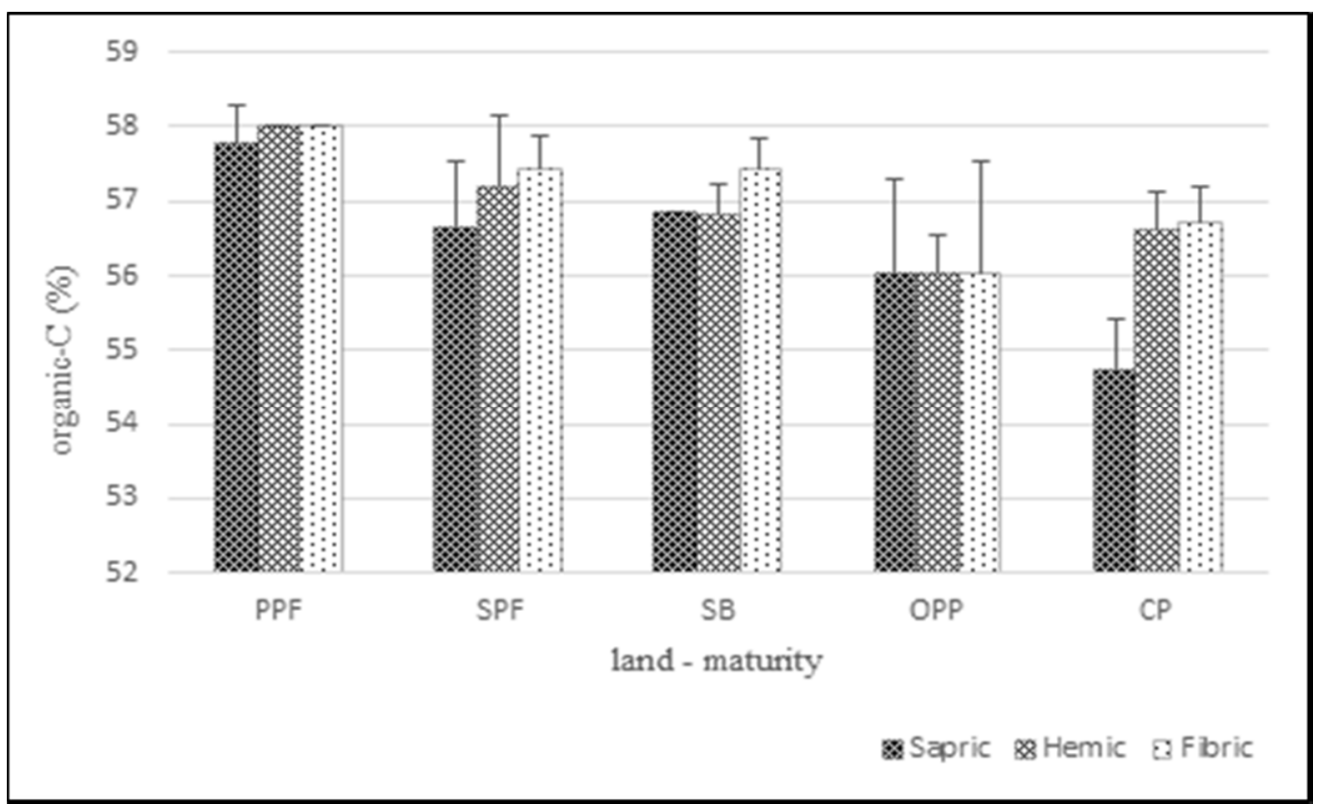

Figure 3. Organic $\mathrm{C}$ on the types of peatland use of primary peat forest (PPF), secondary peat forest (SPF), shrubs (SB), oil palm plantation (OPP) and cornfield (CF) 
Table 2. $\delta^{13} \mathrm{C}$, Ash, and $\mathrm{C} / \mathrm{N}$ ratio on the land use of primary peat forest, secondary peat forest, shrubs, oil palm plantation and cornfield. $\delta 13 \mathrm{C}$, Ash and $\mathrm{C} / \mathrm{N}$ ratio are given as mean with SD.

\begin{tabular}{ccrrr}
\hline Land & Maturity & \multicolumn{1}{c}{$\delta^{13} \mathrm{C}(\%)$} & \multicolumn{1}{c}{ Ash (\%) } & \multicolumn{1}{c}{ C/N ratio } \\
\hline Primary peat forest & Sapric & $-27.05 \pm 0.59$ & $0.4 \pm 0.94$ & $35.45 \pm 0.16$ \\
$($ PPF $)$ & Hemic & $-24.97 \pm 0.63$ & 0.0 & $54.11 \pm 0.09$ \\
& Fibric & $-18.94 \pm 0.39$ & 0.0 & $53.59 \pm 0.21$ \\
Secondary peat forest & Sapric & $-27.90 \pm 0.28$ & $2.3 \pm 1.25$ & $24.66 \pm 0.08$ \\
$($ SPF) & Hemic & $-25.78 \pm 0.26$ & $1.4 \pm 0.94$ & $40.12 \pm 0.13$ \\
& Fibric & $-19.32 \pm 0.43$ & $1.0 \pm 0.82$ & $48.03 \pm 0.10$ \\
Shrubs & Sapric & $-29.29 \pm 0.22$ & $2.0 \pm 0.47$ & $31.37 \pm 0.21$ \\
$($ SB) & Hemic & $-27.19 \pm 0.26$ & $2.0 \pm 0.82$ & $41.38 \pm 0.99$ \\
& Fibric & $-18.78 \pm 0.30$ & $1.0 \pm 0.47$ & $49.18 \pm 0.57$ \\
Oli palm plantation & Sapric & $-26.65 \pm 0.30$ & $3.6 \pm 2.16$ & $35.10 \pm 0.11$ \\
$($ OPP) & Hemic & $-24.00 \pm 0.44$ & $2.4 \pm 0,00$ & $43.48 \pm 0.29$ \\
& Fibric & $-18.95 \pm 0.62$ & $1.4 \pm 0.47$ & $57.35 \pm 0.22$ \\
Corn field & Sapric & $-28.24 \pm 0.29$ & $5.6 \pm 1.25$ & $35.60 \pm 0.13$ \\
$($ CF) & Hemic & $-26.49 \pm 0.56$ & $2.4 \pm 0.82$ & $43.10 \pm 0.46$ \\
& Fibric & $-19.18 \pm 0.71$ & $2.2 \pm 0.47$ & $52.09 \pm 0.08$ \\
\hline
\end{tabular}

\section{land - maturity}

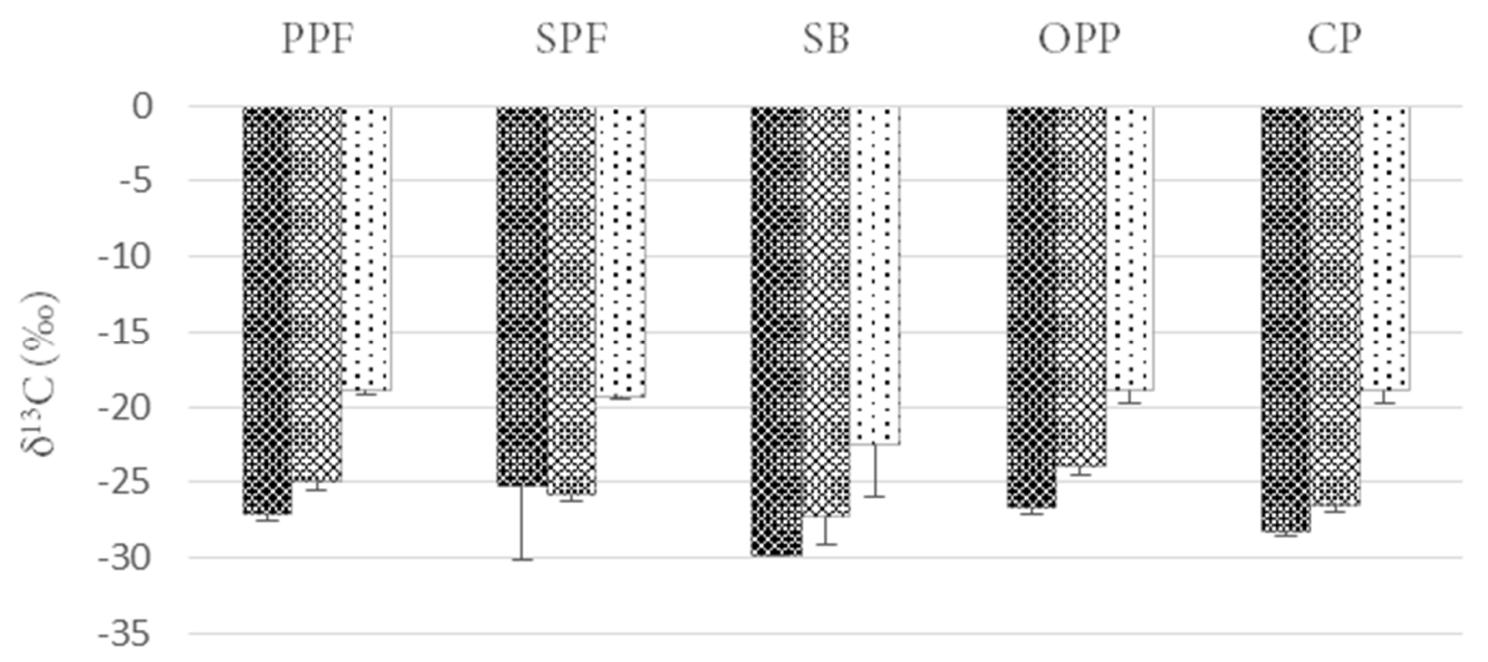

Sapric Hemic Gibric

Figure 4. The $\delta^{13} \mathrm{C}$ on the types of peatland use of primary peat forest (PPF), secondary forest (SPF), shrubs $(\mathrm{SB})$, oil palm plantation (OPP) and cornfield (CF) 
Such conditions may change the characteristics of land such as the height of the water table and the physical and chemical characteristics of peat soil. A previous study by Nusantara and Djohan 2014 showed that change in shallow watertable depth in the forest area to the water-table depth in the SB, OPP, and CF (Table 1). Well-drained and aerated peat land increases the decomposition rate of peat materials, resulting in the physical characteristics of land such as low bulk density and soil porosity, high soil compaction; chemical feature such as low organic $\mathrm{C}$ content while ash content increases as well as decrease ratio $\mathrm{C} / \mathrm{N}$ (Figure 3 and Table 2). Also, according to (Usuga et al. 2010), the increase of ash content in the top layer of drained peatland is from the peat materials whose organic materials had disappeared due to the decomposition process. Soil ash content has the potential to provide the quantitative estimation of peatland $\mathrm{C}$ loss (Krüger et al. 2015). The increase of ash content and decrease ratio $\mathrm{C} / \mathrm{N}$ indicated the loss of $\mathrm{C}$, particularly because of the decomposition process of organic matters.

Stable ${ }^{13} \mathrm{C}$ isotope $\left(\delta^{13} \mathrm{C}\right)$

The $\delta^{13} \mathrm{C}$ based on the peat maturity in the study area ranged from $-29.81 \%$ to $-18.94 \%$ (Figure. 4 ). The negative sign means a ${ }^{13} \mathrm{C} /{ }^{12} \mathrm{C}$ sample greater than ${ }^{13} \mathrm{C} /{ }^{12} \mathrm{C}$ Standart (PDB). More negative $\delta^{13} \mathrm{C}$ is obtained on peat with sapric than humic and fibric. The $\delta^{13} \mathrm{C}$ based on the peat maturity indicated various patterns with a tendency of fibric $\delta^{13} \mathrm{C}$ was higher than hemic and sapric, with their average value of $19.744 \%$, $-25.688 \%$, $-27.403 \%$ respectively. Meanwhile, based on the land use, $\delta^{13} \mathrm{C}$ was varied in which the tendency pattern of SPF (-23.2\%o), PPF (-23.48\%o) was higher than OPP (-23.65\%o), CF (-24.56\%o), SB (-26.5\%o) respectively. Test between the land use with soil organic $C$ there is a difference, but for peat, maturity showed no difference. Corganic arable land was significantly different from forest areas but not different from shrubland. Test between the maturity of peat with peat $\delta^{13} \mathrm{C}$ there is a difference, but for the land use did not show a difference. $\delta^{13} \mathrm{C}$ in sapric significantly different from fibric or hemic.

Based on the peat maturity, sapric has $\delta^{13} \mathrm{C}$ lower than hemic and fibric in the deeper layers. The $\delta^{13} \mathrm{C}$ enrichment was $1.73 \%$ and $7.66 \%$ from hemic and fibric toward sapric. The same opinion was suggested by (Billings and Richter (2006) that $\delta^{13} \mathrm{C}$ increased by $1.1 \%, 1.3 \%$ and $2.3 \%$ from upper layers $(0-7.5 \mathrm{~cm})$ to deeper layers $(7.5-15 \mathrm{~cm})$ in 1962 , 1977,1997 , respectively. $\delta^{13} \mathrm{C}$ of upper layers of native forest $(0-7.5 \mathrm{~cm})$ increased by $2 \%$ while on deeper layers $(30-100$ $\mathrm{cm}$ ) increased by $3 \%$ (Rhoades et al. 2000). In the tropic, the $\delta^{13} \mathrm{C}$ enrichment until 2-4\%o (Bernoux et al. 1998). Other studies, for example, in primary peat forest in Jambi Province, was known that increasing of $\delta^{13} \mathrm{C}$ amounted to $1.6 \%$ and $2 \%$ at $10-20 \mathrm{~cm}$ and $20-30 \mathrm{~cm}$ depth of peat soil upper layers, respectively (Ueda et al. 2005). Upland soils in Maya
Lowland, Guatemala, display $\delta^{13} \mathrm{C}$ enrichment until $8.56 \%$ (Beach et al. 2011). On the contrary, in the peat bog, Japan, a decrease was $4.1 \%$ at a depth of 0.5-4.5 m (Akagi et al. 2004).

Based on land use, forest area (PPF and SPF) has $\delta^{13} \mathrm{C}$ higher than OPP, CF, and SB. It increased by 3.3\%o and $3.02 \%$ of SB against SPF and PPF. This condition is opposite on clay soil that $\delta^{13} \mathrm{C}$ decreased by $1 \%$ and $3.4 \%$ after 7 and $35 \mathrm{yr}$ of maize cultivation against the forest, respectively (Balesdent et al. 1998). The same condition was suggested by (Rhoades et al. 2000) that $\delta^{13} \mathrm{C}$ decreased by $4.6 \%$ and $3.9 \%$ of sugar cane and mixed-species pasture against the oldgrowth forest, respectively.

At this site, the cause of higher isotopic enrichment at a depth of peat soil and land use may be associated with, as follows: first, probably caused by combustion during peatland cultivation. This ${ }^{13} \mathrm{C}$-depleted is incorporated into vegetation and subsequently into SOM, generating a ${ }^{13} \mathrm{C}$-depleted signature in surface soils relative to the older, more ${ }^{13} \mathrm{C}$ enriched material deeper in profile (Billings and Richter 2006). Second, canopy effect and differences between plant functional group (for example, evergreen plant are more ${ }^{13} \mathrm{C}$ enriched by $\sim 1 \%$ ) (Stuiver and Braziunas 1987). Third, the influence of increasing the age of soil organic matter. (Trumbore 2000) argued that the age of soil organic matter increased as a function of the depth and often assumed increasing $\delta^{13} \mathrm{C}$ by the depth of soil. The fraction of organic matter contained on an old organic matter associated with the increasing isotope signature (Tiessen et al. 1982) (Billings and Richter 2006). This statement is consistent with the theory of Suess Effect that the increase of $\delta^{13} \mathrm{C}$ in depth of peat soil is connected to peat material much older. Fourth, ash content. The ash content is an indicator of the peat maturity in the decomposition of organic matter. Sapric has a high ash content than hemic and fibric (Table 2). At the further peat decomposition of organic matter caused by changing anaerobic to aerobic conditions. On different of land use also shows the difference in ash content which CF and OPP have a higher ash content than the forest area (Table 2). An increase in the value of $\delta^{13} \mathrm{C}$ indicates anaerobic conditions, especially in the natural spot (Krüger et al. 2015) characterized by low ash content. Fifth, $\mathrm{C} / \mathrm{N}$ ratio. Low $\mathrm{C} / \mathrm{N}$ ratio are in paralel with low $\delta^{13} \mathrm{C}$ values and vice versa (Table 2) which is congruent with the result from (Krüger et al. 2015). All sites show a possitive correlation between $\delta^{13} \mathrm{C}$ and $\mathrm{C} / \mathrm{N}$ ratio although the strength of correlation varies (Table 3 ). A close correlation indicates that decomposition is driving the stable isotope values (Jones et al. 2010).

\section{Conclusion}

The impact of changing in tropical peat forest to another land uses tend to decrease the SOC and $\delta^{13} \mathrm{C}$. It is might be 
Table 3. Correlation between $\delta^{13} \mathrm{C}$ and $\mathrm{C} / \mathrm{N}$ ratio at primary peat forest, secondary peat forest, shrubs, oil palm plantation and corn field with peat maturity

\begin{tabular}{|c|c|c|}
\hline Land & Maturity & $\mathrm{R}$ \\
\hline \multirow[t]{3}{*}{ PPF } & Sapric & 0.98 \\
\hline & Hemic & 0.97 \\
\hline & Fibric & 0.99 \\
\hline \multirow[t]{3}{*}{ SPF } & Sapric & 0.62 \\
\hline & Hemic & 0.93 \\
\hline & Fibric & 0.88 \\
\hline \multirow[t]{3}{*}{ SB } & Sapric & 0.99 \\
\hline & Hemic & 0.73 \\
\hline & Fibric & 0.90 \\
\hline \multirow[t]{3}{*}{ OPP } & Sapric & 0.69 \\
\hline & Hemic & 0.99 \\
\hline & Fibric & 0.10 \\
\hline \multirow[t]{3}{*}{$\mathrm{CF}$} & Sapric & 0.96 \\
\hline & Hemic & 0.13 \\
\hline & Fibric & 0.68 \\
\hline
\end{tabular}

due to the changing in its environmental conditions from anaerobic to aerobic conditions. There are similar trends between the SOC and $\delta^{13} \mathrm{C}$, based on the peat maturity and land use On the peat soil upper layers, sapric had $\mathrm{C}$ content and $\delta^{13} \mathrm{C}$ lower than fibric on the deeper layers. On types of land, the PPF and SPF have a C content and $\delta^{13} \mathrm{C}$ higher than the other land use. Changing of tropical peat forest to another land uses, especially agricultural tends to lower $\mathrm{C}$ $\delta^{13} \mathrm{C}$ soil and peat soil. $\mathrm{C}$ dynamics of soil due to land conversion is affected by changes in anaerobic to aerobic conditions on peat soil. This condition causes the acceleration of the rate of decomposition and mineralization of organic matter soils. The opposite situation occurs in forest areas that have deposits of soil and $\delta^{13} \mathrm{C} \mathrm{C}$ higher, and maturity fibric has deposits $\mathrm{C}$ soil greater than sapric and hemic.

\section{Reference}

Agus, Fahmuddin, Kurniatun Hairiah, Anny Mulyani, and World Agroforestry Centre (ICRAF). 2011. Pengukuran cadangan karbon tanah gambut. Bogor, Indonesia: World Agroforestry Centre (ICRAF).

Akagi, Tasuku, Kotaro Minomo, Natsuki Kasuya, and Toshio Nakamura. 2004. Variation in carbon isotopes of bog peat in the ozegahara peatland, Japan. Geochemical Journal, 38 (4): 299-306. https://doi.org/10.2343/geochemj.38.299.

Balesdent, J, E Besnard, D Arrouays, and C Chenu.1998. The Dynamics of carbon in particle-size fractions of soil in a forest -cultivation sequence, Plant and soil, 201:49-51..

Beach, Timothy, Sheryl Luzzadder-Beach, Richard Terry, Nicholas Dunning, Stephen Houston, and Thomas Garrison. 2011.
Carbon Isotopic Ratios of Wetland and Terrace Soil Sequences in the Maya Lowlands of Belize and Guatemala. Catena, 85 (2): 109-18. https://doi.org/10.1016/ j.catena.2010.08.014.

Bernoux, Martial, Carlos C Cerri, Christopher Neill, and Jener F.L de Moraes. 1998. The use of stable carbon isotopes for estimating soil organic matter turnover rates. Geoderma, 82 (1 -3): 43-58. https://doi.org/10.1016/S0016-7061(97)00096-7.

Billings, S. A., and D. D. Richter. 2006. Changes in stable isotopic signatures of soil nitrogen and carbon during 40 years of forest development. Oecologia, 148 (2): 325-33. https:// doi.org/10.1007/s00442-006-0366-7.

Brady, Nyle C., and Ray R. Weil. 2007. The nature and properties of soils, 14th Edition. 14 edition. Upper Saddle River, N.J: Pearson.

Choi, Woo-Jung, Scott X. Chang, and Jagtar S. Bhatti. 2007. Drainage affects tree growth and $\mathrm{c}$ and $\mathrm{n}$ dynamics in a minerotrophic peatland. Ecology, 88 (2): 443-53. https:// doi.org/10.1890/0012-9658(2007)88[443:datgac]2.0.CO;2.

Del Galdo, Ilaria, Johan Six, Alessandro Peressotti, and M. Francesca Cotrufo. 2003. Assessing the impact of land-use change on soil $\mathrm{C}$ sequestration in agricultural soils by means of organic matter fractionation and stable $\mathrm{C}$ isotopes. Global Change Biology, 9 (8): 1204-13. https://doi.org/10.1046/ j.1365-2486.2003.00657.x.

Farmer, Jenny. 2011. Assessing existing peatland models for their applicability for modelling greenhouse gas emissions from tropical peat soils. Translated by Jenny Farmer, Robin Matthews, Jo U Smith, Pete Smith, and Brajesh K Singh. Current opinion in environmental sustainability, 3 (5): 339-49. https://doi.org/10.1016/j.cosust.2011.08.010.

- - - 2014. Comparison of methods for quantifying soil carbon in tropical peats. Translated by Jenny Farmer, Robin Matthews, Pete Smith, Charlie Langan, Kristell Hergoualc'h, Louis Verchot, and Jo U. Smith. Geoderma, 214-215: 17783. https://doi.org/10.1016/j.geoderma.2013.09.013.

Firdaus, Mohd Suffian, Seca Gandaseca, Osumanu Haruna Ahmed, and A. M. Nik Muhamad. 2010. Effect of converting secondary tropical peat swamp forest into oil palm plantation on selected peat soil physical properties. American Journal of Environmental Sciences, 6 (4): 402-5.

Hooijer, A., S. Page, J. G. Canadell, M. Silvius, J. Kwadijk, H. Wösten, and J. Jauhiainen. 2010. Current and future $\mathrm{CO}_{2}$ emissions from drained peatlands in Southeast Asia. Biogeosciences, 7 (5): 1505-14. https://doi.org/10.5194/bg-7-1505 -2010 .

Jones, M. C., D. M. Peteet, and R. Sambrotto. 2010. Late-glacial and Holocene $\delta 15 \mathrm{n}$ and $\delta 13 \mathrm{c}$ variation from a Kenai Peninsula, Alaska Peatland. Paleogeography, Palaeoclimatology, Palaeoecology, 293 (1/2): 132-43.

Krüger, J. P., J. Leifeld, S. Glatzel, S. Szidat, and C. Alewell. 2015. Biogeochemical indicators of peatland degradation - a case study of a temperate bog in Northern Germany. Biogeosciences, 12 (10): 2861-71. https://doi.org/10.5194/bg-12-2861 $-2015$.

Lane, Chad S., Sally P. Horn, and Claudia I. Mora. 2004. Stable carbon isotope ratios in lake and swamp sediments as a proxy for prehistoric forest clearance and crop cultivation in the neotropics. Journal of Paleolimnology, 32 (4): 37581. https://doi.org/10.1007/s10933-004-0259-x.

Limpens, J, F Berendse, C Blodau, J G Canadell, C Freeman, J Holden, N Roulet, H Rydin, and G Schaepman-Strub. 2008. Peatlands and the carbon cycle: from local processes to global implications - a synthesis. Biogeosciences, 5: 14751491.

Marin-Spiotta, Erika, Whendee L. Silver, Christopher W. Swanston, and Rebecca Ostertag. 2009. Soil organic matter dynamics during 80 years of reforestation of tropical pastures. Global Change Biology, 15 (6): 1584-97. https://doi.org/10.1111/ j.1365-2486.2008.01805.x. 
Monde, A., N. Sinukaban, K. Murtilaksono, and N. Pandjaitan. 2008. Dinamika karbon (C) akibat alih guna lahan hutan menjadi lahan petanian. Jurnal Agroland, 15 (1): 2226.

Notohadiprawiro. T. 1985. Selidik cepat ciri tanah di lapangan. Ghalia Indonesia.

Nusantara, Rossie Wiedya, and Tjut Sugandawaty Djohan. 2014. Emisi $\mathrm{CO}_{2}$ tanah akibat alih fungsi lahan hutan rawa gambut di Kalimantan Barat. 21 (3): 9.

Ojanen, Paavo, Kari Minkkinen, Annalea Lohila, Tiina Badorek, and Timo Penttilä. 2012. Chamber measured soil respiration: a useful tool for estimating the carbon balance of peatland forest soils. Forest Ecology and Management, 277: 132 -40. https://doi.org/10.1016/j.foreco.2012.04.027.

Page, Susan E, Christopher J Banks, and John O Rieley. 2011. Tropical peatlands: distribution, extent and carbon storage uncertainties and knowledge gaps, 8 .

Page, Susan, Agata Hosciło, Henk Wösten, Jyrki Jauhiainen, Marcel Silvius, Jack Rieley, Henk Ritzema, et al. 2009. Restoration ecology of lowland tropical peatlands in Southeast Asia: Current Knowledge and Future Research Directions. Ecosystems, 12 (6): 888-905. https://doi.org/10.1007/s10021008-9216-2.

Page, Susan, John O’Neil Rieley, and Christopher Banks. 2010. Global and regional importance of the tropical peatland carbon pool. Global Change Biology, 17 (2): 798. https:// doi.org/10.1111/j.1365-2486.2010.02279.x.

Prentice, A. J., and E. A. Webb. 2010. A comparison of extraction techniques on the stable carbon-isotope composition of soil humic substances. Geoderma, 155 (1/2): 1-9.

Qiming, Liu, Wang Shijie, Piao Hechun, and Ouyang Ziyuan. 2003. The variation of soil organic matter in a forest-cultivation sequence traced by stable carbon isotopes. Chinese Journal of Geochemistry, 22 (1): 83-88. https://doi.org/10.1007/ BF02831548.

Radjagukguk, Bostang. 2000. Perubahan sifat-sifat fisik dan kimia tanah gambut akibat reklamasi lahan gambut untuk pertanian. Jurnal Ilmu Tanah Dan Lingkungan 2 (2000). http://i-lib.ugm.ac.id/jurnal/detail.php?dataId=6467.

Rhoades, Charles C., Gregory E. Eckert, and David C. Coleman. 2000. Soil carbon differences among forest, agriculture, and secondary vegetation in Lower Montane Ecuador. Ecologi$\begin{array}{lllll}\text { cal Applications, } 10 & \text { (2): } 497 . & \mathrm{https} / /\end{array}$ doi.org/10.2307/2641109.

Sarkhot, D. V. 2007. Effects of forest management intensity on carbon and nitrogen content in different soil size fractions of a North Florida spodosol. Translated by D. V. Sarkhot, N. B. Comerford, E. J. Jokela, and J. B. Reeves III. Plant and Soil, 294 (1-2): 291-303. https://doi.org/10.1007/s11104007-9255-z.

Satrio, A. E., S. Gandaseca, O. H. Ahmed, and N. M. A. Majid. 2009. Effect of logging operation on soil carbon storage of a tropical peat swamp forest. American Journal of Environmental Sciences, 5 (6): 748-52.

Stuiver, Minze, and Thomas F. Braziunas. 1987. Tree cellulose $13 \mathrm{c} /$
$12 \mathrm{c}$ isotope ratios and climatic change. Nature, 328 (6125): 58. https://doi.org/10.1038/328058a0.

Tan, Zhengxi, and Rattan Lal. 2005. Carbon sequestration potential estimates with changes in land use and tillage practice in Ohio, USA. Agriculture, Ecosystems \& Environment, 111 (1 -4): 140-52. https://doi.org/10.1016/j.agee.2005.05.012.

Tiessen, H., J. W. B. Stewart, and J. R. Bettany. 1982. Cultivation effects on the amounts and concentration of carbon, nitrogen, and phosphorus in grassland soils. Agronomy Journal, 74 (5): 831 . https://doi.org/10.2134/ agronj1982.00021962007400050015x.

Tomich, T. P, Van Noordwijk, M., and Budidarsono, s., eds. 1985. alternatives to slash-burn in Indonesia: Summary Report and Synthesis of Phase II. ICRAF.

Trumbore, Susan. 2000. Age of soil organic matter and soil respiration: radiocarbon constraints on belowground $\mathrm{C}$ dynamics. Ecological Applications, 10 (2): 14.

Ueda, Shingo, Chun-Sim U. Go, Shigehiro Ishizuka, Haruo Tsuruta, Anas Iswandi, and Daniel Murdiyarso. 2005. Isotopic assessment of $\mathrm{CO}_{2}$ production through soil organic matter decomposition in the tropics. Nutrient Cycling in Agroecosystems, 71 (1): 109-16. https://doi.org/10.1007/s10705-004 -1197-8.

Usuga, Juan Carlos Loaiza, Jorge Andrés Rodríguez Toro, Mailing Vanessa Ramírez Alzate, and Álvaro de Jesús Lema Tapias. 2010. Estimation of biomass and carbon stocks in plants, soil and forest floor in different tropical forests. Forest Ecology and Management, 260 (10): 1906-13. https:// doi.org/10.1016/j.foreco.2010.08.040.

Wösten, J. H. M., E. Clymans, S. E. Page, J. O. Rieley, and S. H. Limin. 2008. Peat-water interrelationships in a tropical peatland ecosystem in Southeast Asia. Catena, 73 (2): 212 24. https://doi.org/10.1016/j.catena.2007.07.010. 